\title{
environments
}

ISSN 2076-3298

www.mdpi.com/journal/environments

Article

\section{Consumers' Willingness to Pay for Cabbage with Minimized Pesticide Residues in Southern Benin}

Faustin Vidogbéna ${ }^{1,2, \dagger}$, Anselme Adégbidi ${ }^{3, \dagger}$, Rigobert Tossou ${ }^{2, \dagger}$, Françoise Assogba-Komlan ${ }^{3, \dagger}$, Thibaut Martin ${ }^{4,5, \dagger}$, Mathieu Ngouajio ${ }^{6, \dagger}$, Serge Simon ${ }^{3,4, \dagger}$, Laurent Parrot ${ }^{4, \dagger}$ and

Kerstin K. Zander ${ }^{7, *}$

1 Centre Régional pour la Promotion Agricole (CeRPA), Abomey-Calavi 01 BP 477, Benin; E-Mail: vifaroho@yahoo.fr

2 Faculty of Agricultural Sciences, University of Abomey-Calavi, Cotonou 01 BP 526, Benin; E-Mail: ctossou2000@yahoo.fr

3 Institut National des Recherches Agricoles du Bénin (INRAB), Cotonou 01 BP 884, Benin; E-Mails: ansadegbidi@yahoo.fr (A.A.); fakvine60@yahoo.fr (F.A.-K.); serge.simon@cirad.fr (S.S.)

4 Agricultural Research for Development, UR Hortsys, Montpellier Cedex 5, France;

E-Mails: thibaud.martin@cirad.fr (T.M.); laurent.parrot@cirad.fr (L.P.)

5 Plant Health Department, International Centre of Insect Physiology and Ecology (ICIPE), Nairobi P.O. Box 30772 - 00100, Kenya

6 Department of Horticulture, Michigan State University, East Lansing, MI 48824, USA; E-Mail: ngouajio@msu.edu

7 The Northern Institute, Charles Darwin University, Darwin 0909, Australia; E-Mail: kerstin.zander@cdu.edu.au

$\dagger$ These authors contributed equally to this work.

* Author to whom correspondence should be addressed; E-Mail: Kerstin.zander@cdu.edu.au; Tel.: +61-8-8946-7368; Fax: +61-8-8946-7175.

Academic Editor: Yu-Pin Lin

Received: 20 June 2015 / Accepted: 16 September 2015 / Published: 1 October 2015

Abstract: Cabbage (Brassicaceae) is one of the most frequently consumed exotic vegetables in Benin and also the most affected by insects. To meet growing food demand, farmers rely heavily on synthetic pesticides that are harmful for themselves, consumers and the environment. Integrated pest management has been proposed as the means to improve vegetable productivity and quality in many developing countries. One approach is to substitute pesticides with physical barriers to insects, like nets. Here, we assess consumers' 
perceptions about cabbage and their purchasing behavior towards cabbage that was produced using these nets in two major cities in Benin. Results indicate that consumers are aware of the health risks associated with intensive use of pesticides but were not able to recognize the quality difference between cabbage produced under nets from those using pesticides. All consumers were willing to pay a price premium for cabbage with minimized pesticides residues compared with conventionally produced cabbage, the average premium being $38 \%$. Women, older, highly educated consumers and those able to distinguish cabbage qualities were willing to pay the most. We suggest that farmers will obtain higher prices if their production of cabbage with preferred characteristics is accompanied by an improved marketing strategy.

Keywords: contingent valuation; eco-friendly production; healthy food; IPM; premium price; purchasing decision; West Africa

\section{Introduction}

In a world of 9.5 billion people, global demand for food has to be met with minimal increases in land, water, fossil fuels and impact on the environment [1,2]. It is estimated that $60 \%$ of the world population will reside in cities by 2030. Sub-Saharan Africa (SSA), previously considered the least urbanized zone in the world, is urbanizing rapidly [3] with an urban population growth of $600 \%$ in the last 35 years. The boom in urbanization has resulted in a steep increase in demand for food, especially high value crops such as fruits, vegetables and other horticultural crops [4]. Food production is no longer seen simply as providing nutrition for a growing population but also as contributing to poverty reduction, better health outcomes and conservation of natural resources [5-7].

Over the past couple of decades, urban agriculture has gained increasing importance as a viable strategy for resource-limited people to generate additional income and to reduce their reliance on cash income for food by growing their own $[8,9]$. However, because of demand driven pressure of a growing urban population demanding fresh food, food production, and urban agriculture in particular, are inevitability linked to indiscriminate use of pesticides. These both harm the environment [10] and expose many people to toxic pesticides [11-13]. Vegetable production in Africa is now highly dependent on insecticides, not only in places dominated by large-scale cash crops, but also in small-holder production systems [11,13-15]. Inappropriate application and handling of often banned pesticides can damage the environment [10] and impinge on the health of both those applying the pesticides and the consumers buying crops and vegetables [11-13,16-20]. Nearly $75 \%$ of the 200,000 deaths associated with pesticide poisoning occur in developing countries even though they use only $15 \%$ of global pesticide supply [21,22].

In developed countries, both environmental awareness and consumer awareness of healthy and safe food has increased in the last three decades, leading to a significant increase in the demand for safe organic [23-27] products, including those that are pesticide-free, or pesticide residue-reduced [28-33] as well as products from a particular origin [34-37]. While consumer awareness has received considerable research attention in Asia [26,38-41], little has occurred in African countries, with just a 
few case studies from either consumer [42-47] or producer perspectives [20,48]. Most consumer preference studies in African countries relate to bio-fortified foods [49-51].

However, with greater purchasing power, consumers in Africa are consuming more food outside the home [46] and have become more apprehensive about food quality and safety [43]. This creates a market for high quality, safe food produced by urban farmers. One way to increase food productivity with minimized pesticide use is to deploy nets (referred to as eco-friendly nets-EFNs) as a physical barrier to insects. These nets have been trialed in Benin and Kenya through the USAID funded project "Low cost pest exclusion and microclimate modification technologies for small-scale vegetable growers in East and West Africa". The nets are increasingly replacing foliar insecticide spraying in these two countries with the prospect of being adopted in other African countries [11,52-54]. EFNs can reduce pesticide use by at least $70 \%$, sometimes by even $100 \%$ [11,55,56], hence the term "eco-friendly". While the EFNs showed promising results in term of productivity in France [57], Kenya [58,59] and Benin [11,55,56], and also acceptance by farmers [54], nobody has studied consumers' attitudes towards the vegetables and their attributes that can be produced using the nets, i.e., without heavy use of pesticides.

A recent survey carried out in Benin [60] has shown that the cost of producing cabbages (Brassica oleracea L. var. capitata) using EFNs is about $10 \%$ more than without. Understanding consumer behavior will thus help design market incentives for urban farmers, without which sustainable and economically viable production of safe vegetables using EFNs will be challenging. Our study aims to assess (i) consumers' concerns about the use of pesticides in cabbage production, (ii) their preferences for cabbage qualities, and (iii) their willingness-to-pay (WTP) for pesticide-free cabbage produced using EFNs.

We carried out a survey including a contingent valuation (CV), a stated preference elicitation method. Stated preference methods such as CV and choice experiments (CE) rely on peoples' WTP for goods or services whose value is not readily apparent at markets and has become an important evaluation tool for project developers, designers and planners wishing to introduce a new technology such as EFNs [61,62]. The $\mathrm{CV}$, as applied here, can reveal the tradeoff consumers make between paying a higher price and consuming pesticide-free cabbages that had been produced using EFNs instead of cabbages with high pesticide residues. Besides having the potential to provide information to decision-makers about promoting EFNs for vegetable production in urban areas of Benin, our study also contributes to a growing but still relatively small body of literature on consumer preferences for high quality and safe fresh food products in very poor countries.

\section{Materials and Methods}

\subsection{Research Area}

The study was carried out in two major cities in southern Benin, Cotonou and Abomey-Calavi. Cotonou is Benin's largest city and its economic capital, hosting the biggest business centers and almost all public services. Abomey-Calavi is also densely populated and is the education center of Benin with the largest university in the country and many secondary schools (Figure 1). The two cities are roughly the same size with populations of about 700,000 people whilst the total population of Benin is approximately 10 million [63]. Both cities are supplied by urban farmers who grow a large range of exotic vegetables such as lettuce, eggplant, carrot, cabbage, and indigenous vegetables such as chilli pepper, 
sweet pepper, tomato, amaranths, gboma and basilica. Consumers mainly purchase locally produced vegetables from one of the formal markets (there is one per district) or numerous informal markets.

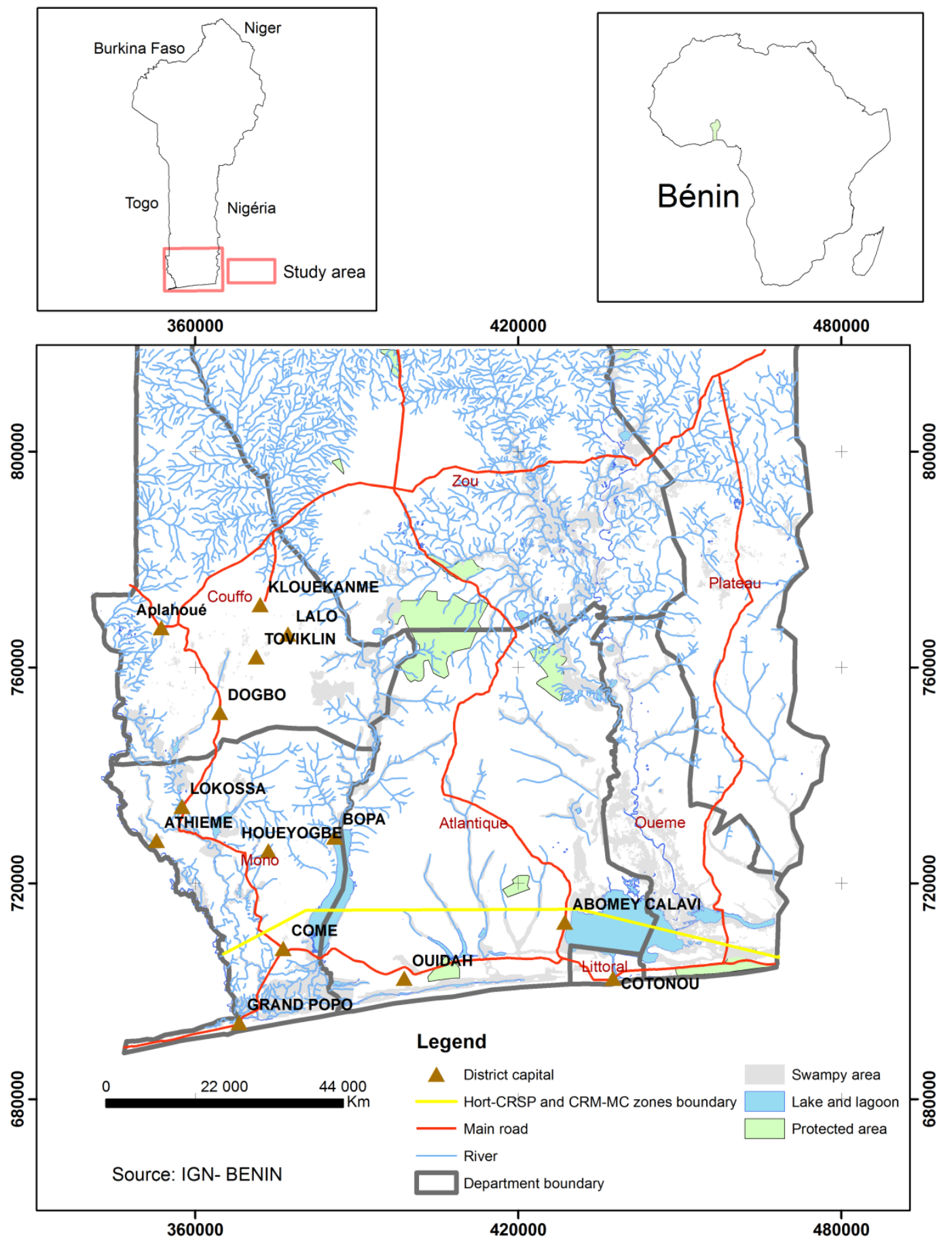

Figure 1. Location of the two survey sites in southern Benin (Cotonou and Abomey Calavi).

The EFNs are cut to cover an iron or wooden frame over a small plot. They are generally made of recyclable polyethylene or, more recently, from starch. The mesh size recommended depends on climate and the size of the pests to be excluded. In tropical Benin both fine mesh nets $(0.4 \mathrm{~mm})$ and larger mesh $(0.9 \mathrm{~mm})$ are used to protect cabbage from major lepidopteran pests (Plutella xylostella, Hellula undalis, Helicoverpa armigera and Spodoptera littoralis) and aphids (Lipaphis erysimi). EFNs are usually removed during daylight hours, when pests specializing in cabbage are inactive, to enable regulation of 
aphids populations by their natural enemies (predators and parasitoids) and to prevent overheating and excessive shade $[11,52,53,55,56]$. While nets should be removed every day, most farmers remove them just three times a week to minimize labor costs [56].

\subsection{Sampling Strategy}

Two enumerators were employed and trained to assist with the interviews that took place between August and September 2013. Face-to-face interviews were implemented in ten urban districts (the lowest administrative entities of a town in Benin). In each district, the sampling process for random sampling of residents was initiated at a crossroads. First, three crossroads were randomly selected per district. The direction of the street segment connecting the starting point to the next crossroad was also chosen randomly. The second starting point was the crossroad situated just below the terminal point of the first segment with the third at the end of the second segment. Each street segment was composed of a set of houses, all of which were assigned a number. Finally, three houses were selected per street segment for household interviews (one respondent per house). This sampling procedure has been successfully applied by others [64] in southern Benin to analyze satisfaction across urban consumers of smallholder-produced teak (Tectona grandis).

A total of 303 sampled houses were selected, 180 in Abomey-Calavi and 123 Cotonou, a sample size similar to other consumer WTP studies $[31,65,66]$. Households not purchasing and consuming cabbage (Brassica oleracea L. var. capitata) were not interviewed. Ninety households (32 in Abomey-Calavi and 58 in Cotonou) in which cabbage was frequently bought for home consumption were finally interviewed for this study.

\subsection{Questionnaire}

We used a structured questionnaire, which, additional to the CV questions, contained various questions eliciting respondents' socio-demographic characteristics and issues relevant to cabbage consumption. We collected information on annual income but also recorded house quality, the main means of transport, and the means of preserving fresh food (see Tables S1.1-S1.3 in supplementary materials) in order to create an indicator of wealth [67]. These complementary indicators were recorded because respondents are often reluctant to reveal their income. When asked about cabbage consumption, respondents were invited to show how cabbage ranked among the vegetables they consumed; whether they distinguish cabbage qualities at the market place; and the criteria they use to guide their choices. Information was also collected on respondents' awareness of farmers' use of nets to replace pesticides.

\subsection{The Contingent Valuation}

Analysis of the change in utility for consumers induced by a change in cabbage quality and the level of payment associated with these qualities is based on McFadden's random utility models [68] which assume utility is comprised of both a deterministic component, which is stated by a consumer or can be observed by a consumer's actions or choices, and a random, unobservable component. The random utility model provides estimates of the probability of a consumer choosing a policy alternative, or in our study, to purchase cabbage of a certain quality at a certain price. The consumer will select pesticide-reduced 
cabbage at a higher price if he or she receives higher utility from it than from conventional cheaper cabbage, i.e., the utility is a function of the cabbage attributes, including its price and consumers' characteristics, including their budget constraints [69]. The tradeoffs consumers make is reflected in their WTP.

The WTP can be revealed through CV. In a CV, hypothetical markets are set up in which consumers' WTP for products (cabbage) are revealed by asking them directly how much more they would pay for a given change in the product's attributes or qualities [70]. Here, we used a modified double-bounded dichotomous choice framework (see [69]).

Given that the cost of producing cabbages using EFNs is about $10 \%$ more than without [60], a $10 \%$ premium was adopted as the lowest bid. Those who were willing to pay at least $10 \%$ more than the prevailing market value were presented with payment card questions to choose from: $11 \%-30 \%, 31 \%-50 \%, 51 \%-70 \%$ and more than $70 \%$. Those respondents who declined the initial bid of $10 \%$, were asked if they would pay something lower than $10 \%$. The assumption of a double-bounded dichotomous approach is that the respondents' answers to both bids are driven by the same underlying WTP value and therefore the second bid can increase the information about respondents' true WTP [71]. The CV question was phrased as follows:

"Are you willing to purchase and consume cabbage if an increase of FCFA $20(\sim 10 \%$ of its current price) is required to support a policy that contributes to a continuous supply of cabbages with minimized pesticide residues?"

A negative response triggered the presentation of a lower bid while a positive response was followed by the presentation of a higher bid. Thus, following [72], possible combinations of responses were "no-no", "no-yes", "yes-no" and "yes-yes".

We acknowledge the ongoing debate on the validity of stated preference methods such as the CV approach. Particularly the potential of a hypothetical response bias (potential difference between real and hypothetical payments) can lead to an overestimation of the WTP results [73-75]. While particularly true for public goods, the effect is much smaller for private goods [73,74] and hence this bias should be reduced in our case as respondents state their WTP for a private good (cabbage). When stating their WTP for private goods, respondents are not misguided by free-riding problems and positive sentiments $[73,75]$. For private goods, it has even been found that respondents understate their WTP to avoid higher payments in real settings [76]. Biases in stating the "true" WTP can also happen if respondents do not have complete knowledge about the good [74], a bias we reduced here by only including people who had previously purchased cabbage. Another factor leading to hypothetical bias is an apparent lack of consequences associated with a respondent's response [73,77]. This hypothetical bias was minimized in our study because the issues are consequential to respondents' own health and well-being and therefore no hypothetical bias should occur (see [78,79]). We did not apply approaches aimed at reducing hypothetical bias, such as cheap talk scripts and certainty adjustments for calibration of WTP estimates [75], because we were confident that bias was already minimized for the reasons noted above. We also reduced hypothetical bias by applying a double-bounded dichotomous choice question format [80]. 


\subsection{Data Processing and Analysis}

To determine the WTP and the factors that might influence these, we applied an ordered probit model. The dependent variable WTP was categorical and coded 0 to 3: 0 when the respondent declined to pay a premium (no-no), (1) when the WTP was positive and lower than 10\% (no-yes), (2) when the WTP was $10 \%$, the starting bid (yes-no), and (3) when the WTP was higher than $10 \%$ (yes-yes). In this study, no one was unwilling to pay a premium, even if less than 10\%, and, consequently, the WTP was not censored (as opposed to, for instance, [47]). Because the dependent variable was ordered, we employed an ordered probit model.

The WTP model can be formulated as [73] WTP $*=\boldsymbol{X}^{\prime} \boldsymbol{\beta}+\varepsilon$, where $W T P *$ is the consumer's latent (unobserved) WTP for safe cabbage, $\boldsymbol{X}$ is a vector of variables affecting the WTP, $\boldsymbol{\beta}$ is a vector of parameters reflecting the relationship between WTP and variables in $\boldsymbol{X}$, and $\varepsilon$ is the error term, normally distributed with mean of zero and a variance of one. If a consumer's unobserved WTP $($ WTP *) falls within a predetermined range, their WTP is assigned a numerical value that reflects the category within which lies their unobserved WTP.

If $\gamma_{\mathrm{j}-1}<W T P \leq \gamma_{\mathrm{j}}$, then $W T P=j-1$ for all $j=1, \ldots, J$, where $j$ is the WTP category selected by the respondent and $\gamma_{\mathrm{k}}$ are category threshold parameters. As the dependent variable had five categories, four unobserved thresholds were expected:

$$
\begin{aligned}
& W T P=0 \text { if a respondent is willing to pay a very low premium }\left[\mathrm{WTP} * \leq \gamma_{1}\right] \\
& W T P=1 \text { if a respondent is willing to pay a low premium }\left[\gamma_{1}<\mathrm{WTP} * \leq \gamma_{2}\right] \\
& W T P=2 \text { if a respondent is willing to pay a medium premium }\left[\gamma_{2}<\mathrm{WTP} * \leq \gamma_{3}\right] \\
& W T P=3 \text { if a respondent is willing to pay a high premium }\left[\gamma_{3}<\mathrm{WTP} * \leq \gamma_{4}\right] \\
& W T P=4 \text { if a respondent is willing to pay a very high premium }\left[\mathrm{WTP} *>\gamma_{4}\right]
\end{aligned}
$$

The probability $(\mathrm{P})$ of a WTP being in one of the five finite categories can be written as:

$$
P(\mathrm{WTP}=j-1)=\Phi\left(\gamma_{\mathrm{j}}-\boldsymbol{X}^{\prime} \boldsymbol{\beta}\right)-\Phi\left(\gamma_{\mathrm{j}-1}-\boldsymbol{X}^{\prime} \boldsymbol{\beta}\right) \forall \mathrm{j} \in \mathrm{J}
$$

where $\Phi$ is the cumulative density function measuring the probability of WTP being less than the respective threshold level.

\section{Results}

\subsection{Respondents' Socio-Demographic Characteristics}

Eight interviews out of a total of 90 were incomplete because respondents did not fully understand the questionnaire and CV question, usually failing to complete the interview. These were not used in the analysis, leaving a final sample of 82 (Table 1). 
Table 1. Sample description and explanatory model variables.

\begin{tabular}{|c|c|c|c|}
\hline $\begin{array}{l}\text { Explanatory } \\
\text { Variable } \\
\end{array}$ & Criterion & Criteria and Coding if Included in Model & $\begin{array}{l}\text { Percentage of } \\
\text { Respondents }\end{array}$ \\
\hline \multirow{2}{*}{ Location } & \multirow{2}{*}{ Residential location and level of urbanization } & Cotonou-urban (1) & 66 \\
\hline & & Abomey-Calavi-regional (0) & 34 \\
\hline \multirow{2}{*}{ Gender } & \multirow{2}{*}{ Respondent's gender } & Male (1) & 45 \\
\hline & & Female $(0)$ & 55 \\
\hline \multirow{3}{*}{ Age } & \multirow{3}{*}{ Respondent's age } & $20-40(1)$ & 74 \\
\hline & & $41-60(2)$ & 26 \\
\hline & & $>60(3)$ & 0 \\
\hline \multirow{3}{*}{ Education } & \multirow{3}{*}{ Respondent's level of education } & No education $(0)$ & 10 \\
\hline & & School in local languages (1) & 25 \\
\hline & & Conventional schooling (2) & 65 \\
\hline \multirow{7}{*}{$\begin{array}{l}\text { Household } \\
\text { size }\end{array}$} & \multirow{7}{*}{$\begin{array}{l}\text { Number of people in one household, all depending } \\
\text { on one household-keeper }\end{array}$} & 1 person $(0)$ & 21 \\
\hline & & $2-3$ persons $(1)$ & 29 \\
\hline & & 4-5 persons $(2)$ & 18 \\
\hline & & $6-7$ persons $(3)$ & 19 \\
\hline & & $8-9$ persons (4) & 7 \\
\hline & & 10 persons $(5)$ & 5 \\
\hline & & More than 10 persons $(6)$ & 1 \\
\hline \multirow{3}{*}{ Income } & \multirow{3}{*}{$\begin{array}{l}\text { Total annual income (in thousands) }=\text { Cash } \\
\text { annually earned from all activities of the } \\
\text { household members) }\end{array}$} & $<$ FCFA 380 or $<€ 580$ (1) & 17 \\
\hline & & between FCFA 380 and 1200 (2) & 27 \\
\hline & & $>$ FCFA 1200 or $>€ 1830$ & 56 \\
\hline \multirow{3}{*}{ Wealth } & \multirow{3}{*}{ Wealth class ${ }^{1}$ (Financial and asset capitals owned) } & Poor (1) & 32 \\
\hline & & Middle (2) & 44 \\
\hline & & Rich (3) & 24 \\
\hline \multirow{2}{*}{$\begin{array}{l}\text { Purchase } \\
\text { frequency }\end{array}$} & \multirow{2}{*}{ Frequency of cabbage purchasing } & At most twice a week $(0)$ & 87 \\
\hline & & More than twice a week (1) & 13 \\
\hline \multirow[b]{2}{*}{ Timeframe } & \multirow{2}{*}{$\begin{array}{l}\text { The time at which respondent think they will be } \\
\text { able to adjust their budget to pay a price premium } \\
\text { for cabbage with minimized pesticides residues }\end{array}$} & Immediately (1) & 95 \\
\hline & & Later $(0)$ & 5 \\
\hline \multirow{3}{*}{$\begin{array}{l}\text { Budget } \\
\text { allocation }\end{array}$} & \multirow{3}{*}{$\begin{array}{l}\text { Percentage of household vegetable budget } \\
\text { allocated to cabbage }\end{array}$} & $<25 \%(1)$ & 57 \\
\hline & & $25 \%(2)$ & 38 \\
\hline & & Between $26 \%$ and $50 \%(3)$ & 5 \\
\hline \multirow{4}{*}{$\begin{array}{l}\text { Place of } \\
\text { purchase }\end{array}$} & \multirow{4}{*}{ Place where respondents buy cabbage } & Farm gate & 9 \\
\hline & & Wholesalers & 5 \\
\hline & & Retailers & 85 \\
\hline & & Others & 1 \\
\hline Recognize & Respondents recognizing cabbage produced using & Yes & 38 \\
\hline pesticide use & pesticides & No & 62 \\
\hline Attributes for & Main attributes from which consumers recognize & Absence of damaged leaves & 18 \\
\hline recognition & cabbage produced using pesticides & Smell of pesticides or smell of rapid rotting & 94 \\
\hline Net use & Respondents are aware of farmers using nets to & Aware (1) & 32 \\
\hline awareness & protect cabbage & Not aware $(0)$ & 68 \\
\hline Pesticide use & Respondents knowing that farmers use pesticides & Yes (1) & 79 \\
\hline knowledge & $\begin{array}{l}\text { when producing cabbage, even when protected by } \\
\text { EFNs }\end{array}$ & No $(0)$ & 21 \\
\hline Ouantity & Respondents meeting required quantity of cabbage & Yes & 98 \\
\hline Quantity & Kespondents meeting required quantity of cabbage & No & 2 \\
\hline & & Yes & 11 \\
\hline Quallty & Kespondents meeting required quality or cabbage. & No & 89 \\
\hline & & Agree & 17 \\
\hline 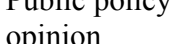 & 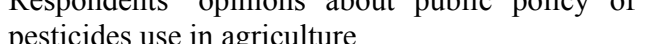 & Indifferent & 15 \\
\hline & pesticiues use in agnicuiture & Disagree & 68 \\
\hline
\end{tabular}

Note: ${ }^{1}$ Wealth was measured by four indicators; Poor $=$ annual income less than $€ 580$, low quality of housing, limited means of transport, few means to preserve fresh foods; Middle = annual income of between $€ 580$ and $€ 1830$, moderate quality of housing, improved means of transport, some means to preserve fresh foods; Rich = annual income greater than $€ 1830$, modern housing, good means of transport, fresh foods readily preserved.

The sample was slightly biased towards women (55\%). Respondents' age ranged between 20 and 60 years with a high share (74\%) being between 20 and 40 years. The majority $(65 \%)$ of respondents were educated at a formal school where French is the official language. Only 10\% never attended a formal school, while the remainder were schooled in local languages. Household size ranged from 1 to 10 with 
a relatively high share of respondents (21\%) living alone. Half of the remainder lived in households of at most five members (the average national household size according to the Bureau of Statistics [63]) while the other half lived in large households with more than five members.

Seventeen percent of respondents said they had an annual income of at most $€ 80$, for $27 \%$ it was between $€ 580$ and $€ 1830$, and the remaining $56 \%$ had an annual income of more than $€ 1830$. Despite this income frame, $76 \%$ of the respondents described themselves as poor and $24 \%$ thought they belonged to the middle class. Almost all respondents (95\%) devoted less than $25 \%$ of their vegetable budget to cabbage while the remainder estimated this proportion to be between $26 \%$ and $50 \%$. Thirty-eight percent of the respondents said that they were aware of the use of EFNs in vegetable production.

\subsection{Consumer Knowledge about Cabbage Quality}

Only a few consumers (38\%) were able to recognize cabbage that was treated with large amounts of synthetic pesticides (Table 1). They distinguished this cabbage by the smell of synthetic pesticides and the degree of leaf alteration. Consumers did not distinguish between smell and damage/spoilage and cabbage without spoilage was said to have a particular and unique smell. Cabbage leaves without holes were also associated with being treated heavily with pesticides. More than $80 \%$ of the consumers (Table 1) were aware of the health risk associated with intensive pesticide use in cabbage production.

\subsection{Access to Cabbage and Purchase Decisions}

Most consumers $(88 \%)$ purchased cabbage at most twice a week for home consumption. The retailers were the main suppliers of the $85 \%$ of those consumers who allocated at most $25 \%$ of their food expenditure on cabbage (Table 1). Almost all respondents (98\%) were satisfied with the quantity of cabbage they could buy but their satisfaction with cabbage quality was much lower, with $89 \%$ of respondents dissatisfied. Almost all consumers (94\%) preferred safe cabbage, indicating a strong concern about health. A third were aware of EFN use to protect cabbage.

More than $80 \%$ of the consumers reported that freshness, number of holes in the leaves, price, size and color influenced their decision to purchase cabbage. Weight was also important to $78 \%$, while smell, taste, texture, and origin were mentioned by $8 \%-26 \%$ of consumer (Table 2 ).

Table 2. Cabbage attributes influencing consumer purchase decisions $(\mathrm{N}=82)$.

\begin{tabular}{|c|c|c|c|}
\hline Explanatory variable & Criterion & Criteria and Coding & Percentage \\
\hline \multirow{2}{*}{ Size } & \multirow{2}{*}{ Size of cabbage is a differential criterion in cabbage choice } & Yes (1) & 84 \\
\hline & & No $(0)$ & 16 \\
\hline \multirow{2}{*}{ Color } & \multirow{2}{*}{ Color of cabbage is a differential criterion in cabbage choice } & Yes (1) & 94 \\
\hline & & No $(0)$ & 6 \\
\hline \multirow{2}{*}{ Hole-free } & \multirow{2}{*}{ Number of holes in cabbage is a differential criterion in cabbage choice } & Yes (1) & 95 \\
\hline & & No $(0)$ & 5 \\
\hline \multirow{2}{*}{ Harmless } & \multirow{2}{*}{$\begin{array}{l}\text { Respondents are aware of health risk associated with heavy use of } \\
\text { synthetic pesticides }\end{array}$} & Yes (1) & 18 \\
\hline & & No $(0)$ & 82 \\
\hline \multirow{2}{*}{ Smell } & \multirow{2}{*}{ Smell of cabbage is a differential criterion in cabbage choice } & Yes (1) & 91 \\
\hline & & No $(0)$ & 9 \\
\hline
\end{tabular}


Table 2. Cont.

\begin{tabular}{|c|c|c|c|}
\hline $\begin{array}{c}\text { Explanatory } \\
\text { variable } \\
\end{array}$ & Criterion & Criteria and Coding & Percentage \\
\hline \multirow{2}{*}{ TaTaste } & \multirow{2}{*}{ Taste of cabbage is a differential criterion in cabbage choice } & Yes (1) & 8 \\
\hline & & No $(0)$ & 92 \\
\hline \multirow{2}{*}{ Freshness } & \multirow{2}{*}{ Freshness of cabbage is a differential criterion in cabbage choice } & Yes (1) & 98 \\
\hline & & No $(0)$ & 2 \\
\hline \multirow{2}{*}{ Spoilage } & \multirow{2}{*}{ Level of spoilage is a differential criterion in cabbage choice } & Yes (1) & 87 \\
\hline & & No $(0)$ & 13 \\
\hline \multirow{2}{*}{ Origin } & \multirow{2}{*}{ Origin of cabbage is a differential criterion in cabbage choice } & Yes $(1)$ & 74 \\
\hline & & No $(0)$ & 27 \\
\hline
\end{tabular}

\subsection{Willingness to Pay for Cabbage with Minimized Pesticide Residues}

On average, consumers were willing to pay a premium of $38 \%( \pm 30 \%)$ or $€ 0.44$ for an average sized residue-reduced cabbage, with a range from $4 \%$ to $129 \%$ (Table 3). Almost half of the consumers (47\%) were willing to pay a premium higher than $10 \%$ of the conventional price of cabbage (which is FCFA 233 or $€ 0.36$ per head), $16 \%$ were willing to pay a premium of $10 \%$ (the threshold WTP) and the remaining $37 \%$ were willing to pay a premium of less than $10 \%$.

Table 3. Respondents' mean and median willingness to pay (WTP) a premium for pesticide residues reduced cabbage (the current average price of cabbage is FCFA 233 or $€ 0.36$ ) $(\mathrm{N}=82)$.

\begin{tabular}{cccc}
\hline & FCFA & Euro & \% of Current Cabbage Price \\
\hline Mean & 89 & 0.14 & 38 \\
Median & 76 & 0.12 & 33 \\
Std. Deviation & 70 & 0.11 & 30 \\
Minimum & 9 & 0.01 & 4 \\
Maximum & 301 & 0.46 & 129 \\
\hline
\end{tabular}

Note: $€ 1=$ FCFA 656

\subsection{Factors Influencing Respondents' Willingness to Pay}

Consumers' WTP for cabbage with minimized pesticide residues was affected by consumers' characteristics and awareness, household expenditure decisions, and cabbage characteristics (Table 4).

Table 4. Results of the ordered probit model $(\mathrm{N}=82)$.

\begin{tabular}{cccc}
\hline Variable & Coefficient & Stand Error & $\boldsymbol{p}>\mathbf{Z}$ \\
\hline Cotonou & $1.32 * *$ & 0.63 & 0.035 \\
Female & $2.72 * * *$ & 0.80 & 0.001 \\
Age & $1.79 *$ & 0.97 & 0.064 \\
Education & $1.24 * *$ & 0.52 & 0.017 \\
Household size & -0.15 & 0.26 & 0.575 \\
Income & 0.19 & 0.43 & 0.656 \\
Wealth & 0.54 & 0.43 & 0.208 \\
Pesticide awareness & $-1.43 * *$ & 0.63 & 0.022 \\
\hline
\end{tabular}


Table 4. Cont.

\begin{tabular}{cccc}
\hline Variable & Coefficient & Stand Error & $\boldsymbol{p}>\mathbf{Z}$ \\
\hline Net use awareness & $1.71 * *$ & 0.78 & 0.029 \\
Budget allocation for cabbage & $1.22 * *$ & 0.57 & 0.031 \\
Purchase frequency & -0.15 & 0.24 & 0.542 \\
Immediate availability & $5.55 * * *$ & 1.86 & 0.003 \\
Size & $-1.80 *$ & 1.01 & 0.075 \\
Color & 1.48 & 1.32 & 0.261 \\
Hole-free & -1.11 & 1.65 & 0.499 \\
Harmless & 0.68 & 0.86 & 0.432 \\
Taste & $-3.57 * * *$ & 1.34 & 0.008 \\
Freshness & $1.87 * *$ & 0.83 & 0.024 \\
Spoilage/Smell & $-3.09 * * *$ & 0.98 & 0.002 \\
Origin & 0.84 & 0.69 & 0.221 \\
$\gamma_{1}$ & 9.73 & 3.36 & \\
$\gamma_{2}$ & 14.10 & 3.68 & \\
$\gamma_{3}$ & 15.29 & 3.76 & \\
$\gamma_{4}$ & 15.61 & 3.77 & \\
$\mathrm{R}^{2}$ & \multicolumn{3}{|}{} \\
Log likelihood & & 0.28 & \\
\hline
\end{tabular}

Note: $* * *$ : significant at $1 \%(p<0.01) ; * *$ : significant at $5 \%(p<0.05) ; *$ significant at $10 \%(p<0.1)$.

Age $(p<0.1)$, being a woman $(p<0.01)$, having a high level of education $(p<0.05)$ and living in Cotonou $(p<0.05)$ positively affected the WTP. Consumers' awareness of farmers using nets to protect cabbage also positively influenced their WTP $(p<0.05)$ whereas pesticide awareness and WTP were negatively correlated $(p<0.05)$. The more budget consumers allocated to purchasing cabbage, the higher their WTP $(p<0.01)$. They were also willing to pay more for safe-to-eat cabbage that was immediately available $(p<0.01)$.

Cabbage characteristics with a significant impact on the WTP were health-related variables such as taste $(p<0.01)$, spoilage $(p<0.01)$, freshness $(p<0.05)$ and size $(p<0.1)$. Whereas taste, spoilage and cabbage size had a negative influence on consumer WTP a premium, freshness had a positive effect. As respondents said that spoilage and smell were highly correlated, we only included spoilage as an explanatory variable in the model.

\section{Discussion}

\subsection{Consumers' Willingness to Pay}

We found that consumers in southern Benin are willing to pay, on average, a $38 \%$ premium for cabbage (that is $38 \%$ of the current market price of cabbage) with minimized pesticides residues. This WTP is high relative to values reported in developed countries. In the USA, 87\% of consumers are reluctant to pay a price premium of more than $10 \%$ of the conventional price for pesticide-free fresh products [28]. Similarly, $68 \%$ of consumers in Italy are unwilling to pay a price premium higher than $10 \%$ for pesticide-free fresh fruits and vegetables [30] and consumer WTP a premium for organic products in Spain was $<25 \%$ [23]. Moreover, these studies showed only 1\% of American consumers [28] and 11\% 
of Italian consumers [30] would pay a premium price of more than $20 \%$ for pesticide-free fresh produce. Here, we found that $47 \%$ of Beninese consumers would pay a premium of more than $20 \%$.

Our study is more in line with findings from similar studies in Benin and other developing countries. Two studies in Benin found that consumers are willing to pay an average premium of more than 50\% for pesticide-free vegetables: for cabbage in the coastal regions of Porto-Novo, Cotonou, Ouidah, Lokossa and Grand-Popo [42] and for pesticide-free vegetables in Cotonou and Grand-Popo [65]. A study from Ghana [47] reported a mean WTP of a $30 \%$ premium for organic watermelons $(€ 0.35$ per $\mathrm{kg}$ for organic $v s . € 0.27$ for conventional watermelons) and about $560 \%$ for organic lettuce $(€ 0.79$ per $\mathrm{kg}$ for organic $v s . € 0.12$ for conventional). Other studies showed a WTP ranging from a $34 \%$ to a $66 \%$ premium for safe kale in Kenya [81] and a WTP a 70\% premium for organic vegetables in Vietnam [66]. Results of a meta-analysis across 25 studies from developed countries and eight from China also demonstrated a higher WTP for organic food products [82].

This higher WTP among consumers in developing countries may be explained by the urge to purchase healthy and safe fresh food, with non-regulated abuse of pesticide use being a more severe problem there than in developed countries. In Benin, repeated and increasing poisoning from fresh food produced in cotton production areas is often reported in local mass media. This publicity and associated concerns over health has probably helped raise awareness among consumers and raised their high WTP for safe food.

\subsection{Demographic Effects}

The coefficient for gender was highly significant $(p<0.01)$ with women being more likely to pay a premium. In Benin, as in many other countries, women buy most groceries for their households [33,44] and, while men tend to provide the income, women tend to manage household health issues [83]. Results from other studies are mixed. Some found no gender differences in WTP for healthy or organic fresh food $[46,47]$ while others reported that women would pay more than men, e.g., for organic apples in the USA [24] and Europe [33] and for organic chicken meat in the USA [27].

Age was also significant, indicating that older consumers would pay more, a finding consistent with one study [27] but not others who found that age was not a significant determinant of WTP for premium fresh foods $[33,38,46,47]$. The positive relationship between age and WTP for healthy fresh food could be because older people were more concerned about health [75].

We also found that better educated consumers were willing to pay higher premiums, consistent with studies from Taiwan for vegetables with minimal pesticide residues [38] and from Vietnam for organic vegetables [66].

While, as reported elsewhere [33,42], household size was not significant, the lack of significant impact of income and wealth class on consumers' WTP (Table 4) was more surprising. While our results did not match those of [65], who concluded that income negatively influences Beninese WTP for pesticide-free cabbage, they do suggest that demand for healthy cabbage extends to all households, not only the richer ones. Given that studies from both developed [27,28,30] and less developed [43,45] countries have found that WTP for organic and "safe" foods is significantly and positively related to income, the lack of relationship in Benin suggests that either the health risk from cabbages is thought to be higher in Benin or concerns about health are greater than in other countries where such studies have been undertaken. 


\subsection{Effect of Location}

Respondents from the more urbanized Cotonou were willing to pay more than those from less urbanized Abomey-Calavi. This finding could be the result of increasing sensitization of the Beninese population concerning the impacts of pesticides on health that is taking place in Cotonou through various advertising and campaigns conducted by NGOs and the government. These initiatives include household visits, strategic groups meetings and communication via mass media.

\subsection{Effects of Cabbage Purchase Behavior}

Demand for cabbage in general, and even more so for healthy cabbage, can be expressed through the frequency with which it is purchased, the quality of the cabbage attributes and the price the consumers are willing to pay for cabbage of the desired quality. Although the frequency of cabbage consumption was not found to be a significant indicator of consumers' WTP, this can be because the frequency of purchasing cabbage is highly dependent on the supply of cabbage of desirable quality. While cabbage is an exotic vegetable that has only recently been introduced to many parts of Africa [84], demand is believed to be increasing $[84,85]$. Thus, consumer demand for cabbage that is healthy and safe to eat may be much higher than is currently the case with respondents saying that, while they could get enough cabbage, it was often not of the quality they desired (Table 2). Indeed, the strong influence of "Immediate availability" on the WTP suggests that consumers would probably already be paying price premiums if safe fresh produce was more readily available.

\subsection{Effects of Cabbage Attributes}

For at least $90 \%$ of the consumers, the decision to purchase a cabbage is guided by its freshness, extent of spoilage, color and smell (Table 2), in line with other studies [44,65,86-88]. Cleanliness and being pleasant to the eye have been reported as the main attributes guiding consumers' decisions in purchasing vegetables [86]. In terms of WTP, three of the four important attributes related to sensory appearance characteristics: spoilage, cabbage size and freshness (Table 4), in line with other studies [42,47], with freshness being particularly important $[47,65]$. The negative sign for cabbage size, although also reported elsewhere [47], was surprising. One reason could be that consumers associate bigger cabbage size with the use of pesticides, and not with cabbage locally produced by farmers using EFNs, i.e., consumers may not believe that large cabbages of bigger size can be produced without excessive use of pesticides.

The fourth attribute that highly influenced consumers WTP was taste. Sensory attributes such as smell and taste are important determinants for respondents to identify healthy and safe to eat cabbage. Bad taste and smell are indicators of contamination with pesticide residues or that the cabbage is starting to rot. Judging the extent of pesticide residue in cabbage by its taste and smell is important for consumers because most farmers in Benin ignore the re-entry and withholding periods after spraying of pesticides [11], harvesting their cabbage so soon after spraying that the smell can be detected by consumers. When farmers comply with the withholding period, however, the smell may no longer be detectable, making it difficult for the consumers to assess whether pesticides have been applied inappropriately.

The origin of cabbage was not a criterion for paying a premium for fresh foods, unlike in many developed countries in which the origin, if labelled appropriately, can indicate a particular taste, 
production method or ethnocentrism associated with a region. Consumers in developed countries prefer products from their home country or region [89,90], as shown by their higher WTP $[35,36,91,92]$. Consumers in Tanzania, on the other hand, would not pay more for food that is from Tanzania compared to other countries [43], which is in line with our results. This difference between developed and developing countries could be because of labelling and awareness for regional products.

\subsection{Effects of Awareness and Knowledge}

Awareness frequently determines preference and WTP for premium fresh foods. This includes awareness of chemical residues and health risks $[42,65]$ and concern about a healthy diet and environmental degradation [28]. Here, we found that consumers who were aware that EFNs had been used by farmers as an alternative to excessive pesticide use were more likely to pay a premium.

Given this positive relationship between awareness and WTP, there is merit in increasing awareness that famers using EFNs use less pesticide to grow their cabbages and that consumers may avoid health problems by purchasing such cabbages. For instance, consumer behavior and WTP may be affected by taking samples of pesticide residues in vegetables just before harvest and making these results publicly available, as was done recently in southern Benin [93]. This could also overcome a lack of trust among consumers, which is evident from our study in the lower WTP among consumers who know that farmers producing cabbages under EFNs do still use small quantities of pesticide to control small insects such as aphids that pass through the net mesh. We think that the lower WTP was because consumers did not believe that the farmers who use EFNs also do not use a lot of pesticides. A similar study [47] also found that consumers who are aware of chemical residues in conventional vegetables are willing to pay less for organic lettuce and watermelons in Ghana, also possibly for lack of trust.

Despite the increasing sensitization of consumers to the use of pesticide, particularly in the urban center of Cotonou, our results show there is a lack of knowledge about the impacts of pesticide and pesticide residues in fresh foods. As a result, while consumers may prefer pesticide free cabbage, they may not have the skills needed to recognize the pesticide residue status of cabbage - indeed they may not be recognizable without chemical analysis that will be beyond the capacity of household consumers. This points to a role for government or NGOs in analyzing and publicizing the pesticide status of the EFN and non-EFN cabbages.

\subsection{Policy Implications}

Cabbage is an exotic vegetable and not yet widely consumed in Benin ( $\sim 30 \%$ of the households). Our results indicate that consumers are not satisfied with the current quality of the cabbage, which is likely to hamper higher levels of consumption. One efficient policy could be to apply minimum quality/safety standards on markets in Benin and enforce a ban on all vegetables that do not meet these standards [87]. While this intervention could be costly for society, as it increases the cost of production and prohibits consumer choice [94], this may be balanced by lower health costs and increased economic productivity from healthy workers.

We discovered a relatively high WTP for health-related attributes. Health concerns from pesticide residues in vegetables in developing countries are growing and should be supported by government subsidies or, integrated into markets by higher premium prices generated through appropriate labelling 
and marketing. We also showed that not all consumers could distinguish between cabbage contaminated by pesticides and those not. Labelling healthy fresh food would therefore help those who wish to buy healthy food. Setting up and marketing using certified labels will require government support, as would the setting up of niche markets. Initially these could be in the form of special zones in conventional markets where only healthy fresh products are sold, although the cost of establishing a labelling system would need external subsidies until costs can be covered by sales. This could be through credits to vegetable farmers' cooperatives from government, NGOs or international donors.

In addition to a need for appropriate labeling and the absence of niche markets, farmers need to be better educated about alternative sustainable gardening practices and the right way to apply pesticides. Farmers who used EFNs were part of a broader project, but once this project has finished, there is no ongoing support and service for farmers to increase awareness of the negative use of pesticides for themselves and consumers, and to learn new practices. Again, government, private or NGOs will need to continue promulgation of new sustainable practices such as EFNs. Currently the information conveyed to farmers is that good yields and vegetables without heavy damage can only be produced by using pesticides. Thus, most farmers will continue to use pesticides with little regard for regulations recommended by the CNAC in application of Rotterdam and Stockholm conventions $[95,96]$. Another sustainable alternative, botanical pesticides, of which a few are registered and were traditionally produced from local raw materials, is no longer possible in peri-urban environments because they have already been over-exploited [20].

Once there is a market for healthy cabbage, farmers should be able to make a living by selling cabbage produced using EFNs at a price at least $10 \%$ higher than the current price for conventional cabbage. Almost half of the consumers (47\%) are willing to pay a premium higher than $10 \%$ of the conventional price of cabbage, suggesting there is a market opportunity for farmers, as the additional costs for farmers to produce cabbage using nets is assumed to be $10 \%$ higher [60]. However, while this premium should be enough for farmers to produce cabbage with the attributes desired by consumers, it also highlights a role for outside agencies in ensuring compliance with any labelling that occurs. If a premium is indeed generated by EFN cabbages, consumers may only trust labelling, and pay the premium, if they are confident that non-EFN cabbages are not being fraudulently mislabelled to benefit from the EFN premium. The actual premium paid by consumers will thus be a trade-off between their desire for a healthier product and the level of trust that the more expensive product they are purchasing does indeed comply with its label.

\section{Conclusions}

This study assessed consumers' perceptions of and purchasing behavior towards "healthy" and "eco-friendly" cabbage in southern Benin. Smell, freshness, and taste were the main factors affecting a decision to purchase. All interviewed consumers are willing to pay a price premium of at least $10 \%$ and, in most cases, $20 \%-70 \%$ on top of the actual cabbage prices if the cabbage was produced with minimized pesticide use. Those consumers who detect the impacts of pesticides on cabbage (pesticide-related spoilage and alterations in taste/smell) are willing to pay less whereas highly educated women and older consumers are willing to pay the highest premiums. Consumers in the capital of Benin would also pay more than those in the more regional areas of the country because they are increasingly sensitized to the 
impacts of pesticides on their health. Similar to studies on organic food and food labelling from developed countries, we recommend the establishment of niche markets and eco/organic labelling for vegetables that are produced without or minimal pesticide use. This will increase the amount of information and knowledge for pesticide-free food and help those consumers who cannot distinguish "pesticide-free" from conventional vegetables. In turn, higher prices for vegetables will allow urban farmers to invest more in sustainable farming technologies such as nets used as physical barriers to insecticides.

\section{Acknowledgments}

This work was part of the project "Low cost pest exclusion and microclimate modification technologies for small-scale vegetable growers in East and West Africa" supported by the Centre de Coopération Internationale pour la recherché Agronomique et le Dévelopement (Cirad) and by the generous support of the United States Agency for International Development (USAID) under Award No. EPP-A-00-09-00004. The contents are the responsibility of Horticulture CRSP project BioNetAgro investigators and do not necessarily reflect the views of USAID or the United States Government. We are grateful for comments and advice on earlier drafts from Augustin Ahoudji, Afio Zannou Désiré Agossou, Pierre Vissoh and Stephen Garnett.

\section{Author Contributions}

Faustin Vidogbéna had the original idea for the study and, with all co-authors carried out the design with the help of Anselme Adégbidi, Laurent Parrot, Serge Simon, Thibaut Martin and Rigobert Tossou. Faustin Vidogbéna, Anselme Adégbidi, Mathieu Ngouajio, Françoise Assogba-Komlan and Laurent Parrot were responsible for carrying out the field work. Faustin Vidogbéna was responsible for data cleaning and analyses. Faustin Vidogbéna, Laurent Parrot and Kerstin K. Zander drafted the manuscript, which was revised by all authors. All authors read and approved the final manuscript.

\section{Conflicts of Interest}

The authors declare no conflict of interest.

\section{References}

1. Godfray, H.C.J.; Beddington, J.R.; Crute, I.A.; Haddad, L.; Lawrence, D.; Muir, J.F.; Pretty, J.; Robinson, S.; Thomas, S.M.; Toulmin, C. Food security: The challenge of feeding 9 billion people. Science 2010, 327, 812-818.

2. Tilman, D.; Balzer, C.; Hill, J.; Befort, B.L. Global food demand and the sustainable intensification of agriculture. Proc. Nat. Acad. Sci. USA 2011, 108, 20260-20264.

3. Sommers, M. Urban youth in Africa. Environ. Urban. 2010, 22, 317-332.

4. Parrot, L.; Dongmo, C.; Ndoumbé, M.; Poubom, M. Horticulture, livelihoods, and urban transition in Africa: Evidence from South-West Cameroon. Agric. Econ. 2008, 39, 245-256.

5. Welch, R.M.; Graham, R.D. A new paradigm for world agriculture: Meeting human needs: Productive, sustainable, nutritious. Field Crops Res. 1999, 60, 1-10. 
6. Dubé, L.; Pingali, P.; Webb, P. Paths of convergence for agriculture, health, and wealth. Proc. Nat. Acad. Sci. USA 2012, 109, 12294-12301.

7. Sayer, J.; Cassman, K.G. Agricultural innovation to protect the environment. Proc. Nat. Acad. Sci. USA 2013, 110, 8345-8348.

8. Zezza, A.; Tasciotti, L. Urban agriculture, poverty, and food security: Empirical evidence from a sample of developing countries. Food Policy 2010, 35, 265-273.

9. FAO. Growing Greener Cities in Africa: First Status Report on Urban and Periurban Horticulture in Africa; Food and Agriculture Organization of the United Nations: Rome, Italy, 2012.

10. Pimentel, D. Amounts of pesticides reaching target pests: Environmental impacts and ethics. J. Agric. Environ. Ethics 1995, 8, 17-29.

11. Martin, T.; Assogba-Komlan, F.; Houndete, T.; Hougard, J.M.; Chandre, F. Efficacy of mosquito netting for sustainable small holders' cabbage production in Africa. J. Econ. Entomol. 2006, 99, $450-454$.

12. Williamson, S.; Ball, A.; Pretty, J. Trends in pesticide use and drivers for safer pest management in four African countries. Crop Prot. 2008, 27, 1327-1334.

13. De Bon, H.; Huat, J.; Parrot, L.; Sinzogan, A.; Martin, T.; Malézieux, E.; Vayssières, J.-F. Pesticide risks from fruit and vegetable pest management by small farmers in sub-Saharan Africa. Agron. Sustain. Dev. 2014, 34, 723-736.

14. Lund, T.; Sæthre, M.-G.; Nyborg, I.; Coulibaly, O.; Rahman, M.H. Farmer field school-IPM impacts on urban and peri-urban vegetable producers in Cotonou, Benin. Int. J. Trop. Insect Sci. 2010, 30, 19-31.

15. Probst, A.; Adoukonou, L.; Amankwah, A.; Diarra, A.; Vogl, C.R.; Hauser, M. Understanding change at farm level to facilitate innovation towards sustainable plant protection: A case study at cabbage production sites in urban West Africa. Int. J. Agric. Sustain. 2012, 10, 40-60.

16. Williamson, S. Breaking the barriers to IPM in Africa: Evidence from Benin, Ethiopia, Ghana and Senegal. In The Pesticide Detox: Towards a More Sustainable Agriculture; Pretty, J., Ed.; Earthscan: London, UK, 2005; pp. 165-180.

17. Amoah, P.; Drechsel, P.; Abaidoo, R.C.; Ntow, W.J. Pesticide and pathogen contamination of vegetables in Ghana's urban markets. Arch. Environ. Contam. Toxicol. 2006, 50, 1-6.

18. Ntow, W.J.; Gijzen, H.J.; Kelderman, P.; Drechsel, P. Farmer perceptions and pesticide use practices in vegetable production in Ghana. Pest Manag. Sci. 2006, 62, 356-365.

19. Timbilla, J.; Nyarko, K. A survey of cabbage production and constraints in Ghana. Ghana J. Agric. Sci. 2006, 37, 93-101.

20. Amoabeng, W.B.; Gurr, G.M.; Gitau, K.W.; Stevenson, P.C. Cost-benefit analysis of botanical insecticide use in cabbage: Implications for smallholder farmers in developing countries. Crop Prot. 2014, 57, 71-76.

21. Darko, G.; Akoto, O. Dietary intake of organophosphorus pesticide residues through vegetables from Kumasi, Ghana. Food Chem. Toxicol. 2008, 46, 3703-3706.

22. Armah, F.A. Assessment of pesticide residues in vegetables at the farm gate: Cabbage (Brassica oleracea) cultivation in Cape Coast, Ghana. Res. J. Environ. Toxicol. 2011, 5, 180-202.

23. Gil, J.M.; Gracia, A.; Sanchez, M. Market segmentation and willingness to pay for organic products in Spain. Int. Food Agribus. Manag. Rev. 2000, 3, 207-226. 
24. Loureiro, M.L.; McCluskey, J.J.; Mittelhammer, R.C. Will consumers pay a premium for ecolabeled apples. J. Consum. Aff. 2002, 36, 203-219.

25. Batte, M.T.; Hooker, N.H.; Haab, T.C.; Beaverson, J. Putting their money where their mouths are: Consumer willingness to pay for multi-ingredient, processed organic food products. Food Policy 2007, 32, 145-159.

26. Zander, K.; Hamm, U. Consumer preferences for additional ethical attributes of organic food. Food Qual. Prefer. 2010, 21, 495-503.

27. Van Loo, E.J.; Caputo, V.; Nayga, R.M.; Meullenet, J.F.; Ricke, S.C. Consumers' willingness to pay for organic chicken breast: Evidence from choice experiment. Food Qual. Prefer. 2011, 22, 603-613.

28. Misra, S.K.; Huang, C.L.; Ott, S.L. Consumer willingness to pay for pesticide-free fresh produce. West. J. Agric. Econ. 1991, 16, 218-227.

29. Eom, Y. Pesticide residue risk and food safety valuation: A random utility approach. Am. J. Agric. Econ. 1994, 76, 760-771.

30. Boccaletti, S.; Nardella, M. Consumer willingness to pay for pesticide-free fresh fruit and vegetables in Italy. Int. Food Agribus. Manag. Rev. 2000, 3, 297-310.

31. Combris, P.; Giraud-Héraud, E.; Bazoche, P.; Hannus, C.; Pinto, A.S.; Berjano, M.; Maia, R. Consumers' willingness to pay for reduced pesticide use in the production of fresh and processed apples. Acta Hortic. 2012, 940, 425-432.

32. Glenk, K.; Hall, C.; Liebe, U.; Meyerhoff, J. Preferences of Scotch malt whisky consumers for changes in pesticide use and origin of barley. Food Policy 2012, 37, 719-731.

33. Bazoche, P.; Combris, P.; Giraud-Héraud, E.; Seabra Pinto, A.; Bunte, F.; Tsakiridou, E. Willingness to pay for pesticide reduction in the EU: Nothing but organic? Eur. Rev. Agric. Econo. 2014, 41, 87-109.

34. Ilbery, B.; Kneafsey, M. Producer constructions of quality in regional speciality food production: A case study from south west England. J. Rural Stud. 2000, 16, 217-230.

35. Loureiro, M.L.; Umberger, W.J. A choice experiment model for beef: What US consumer responses tell us about relative preferences for food safety, country-of-origin labeling and traceability. Food Policy 2007, 32, 496-514.

36. Gao, Z.; Schroeder, T.C. Effects of label information on consumer willingness-to-pay for food attributes. Am. J. Agric. Econo. 2009, 91, 795-809.

37. Tonsor, G.T.; Schroeder, T.C.; Lusk, J.L. Consumer valuation of alternative meat origin labels. J. Agric. Econ. 2013, 64, 676-692.

38. Fu, T.T.; Liu, J.T.; Hammitt, J.K. Consumer willingness to pay for low-pesticide fresh produce in Taiwan. J. Agric. Econ. 1999, 50, 220-233.

39. Vanit-Anunchai, C.; Schmidt, E. Consumer willingness to pay for environmentally friendly produced vegetables in Thailand. Acta Hortic. 2004, 655, 107-113.

40. Posri, W.; Shankar, B.; Chadbunchachai, S. Consumer attitudes towards and willingness to pay for pesticide residue limit compliant "safe" vegetables in northeast Thailand. J. Int. Food Agribus. Mark. 2006, 19, 81-101.

41. Huang, C.H.; Lee, C.H. Consumer willingness to pay for organic fresh milk in Taiwan. China Agric. Econ. Rev. 2014, 6, 198-211. 
42. Nouhoheflin, T.; Coulibaly, O.; Cherry, A.J.; Al-Hassan, R.; Adegbola, P.Y. Consumers’ perception and willingness to pay for organic vegetable in Benin and Ghana. In Proceedings of the Inaugural Symposium, Nairobi, Kenya, 6-8 December 2004.

43. Alphonce, R.; Alfnes, F. Consumer willingness to pay for food safety in Tanzania: An incentive-aligned conjoint analysis. Int. J. Consum. Stud. 2012, 36, 394-400.

44. Acheampong, P.P.; Braima, H.; Ankomah-Danso, A.; Mochiah, M.B. Consumers' behaviors and attitudes toward safe vegetable production in Ghana. A case study of the cities of Kumasi and Cape Cost. Sci. J. Agric. Res. Manag. 2012, 2012, doi:10.7237/Sjarm/109.

45. Lagerkvist, C.J.; Hess, S.; Okello, J.; Karanja, N. Consumer willingness to pay for safer vegetables in urban markets of a developing country: The case of Kale in Nairobi, Kenya. J. Dev. Stud. 2012, 49, 365-382.

46. Probst, L.; Houedjofonon, E.; Mensah, H.A.; Haas, R. Will they buy it? The potential for marketing organic vegetables in the food vending sector to strengthen vegetable safety: A choice experiment study in three West African cities. Food Policy 2012, 37, 296-308.

47. Owusu, V.; Anifory, M.O. Consumer willingness to pay a premium for organic fruit and vegetable in Ghana. Int. Food Agribus. Manag. Rev. 2013, 16, 67-86.

48. Ayuya, O.I.; Gido, E.O.; Bett, H.K.; Lagat, J.K.; Kahi, A.K.; Bauer, S. Effect of certified organic production systems on poverty among smallholder farmers: Empirical evidence from Kenya. World Dev. 2015, 67, 27-37.

49. De Groote, H.; Kimenju, S.C. Comparing consumer preferences for color and nutritional quality in maize: Application of a semi-double-bound logistic model on urban consumers in Kenya. Food Policy 2008, 33, 362-370.

50. Chowdhury, S.; Meenakshi, J.V.; Tomlins, K.I.; Owori, C. Are consumers in developing countries willing to pay more for micronutrient-dense biofortified foods? Evidence from a field experiment in Uganda. Am. J. Agric. Econ. 2011, 93, 83-97.

51. Meenakshi, J.V.; Banerji, A.; Manyong, V.; Tomlins, K.; Mittal, N.; Hamukwala, P. Using a discrete choice experiment to elicit the demand for a nutritious food: Willingness-to-pay for orange maize in rural Zambia. J. Health Econ. 2012, 31, 62-71.

52. Muleke, E.; Saidi, M.; Itulya, F.M.; Martin, T.; Ngouajio, M. Enhancing cabbage (Brassica oleraceae Varcapitata) yields and quality through microclimate modification and physiological improvement using agronet covers. Sustain. Agric. Res. 2014, 3, $24-34$.

53. Muleke, E.; Saidi, M.; Itulya, F.M.; Martin T.; Ngouajio, M. The assessment of the use of eco-friendly nets to ensure sustainable cabbage seedling production in Africa. Agronomy 2013, 3, $1-12$.

54. Vidogbèna, F.; Adégbidi, A.; Tossou, R.; Assogba-Komlan, F.; Ngouajio, M.; Martin, T.; Simon, S.; Parrot, L.; Zander, K.K. Control of vegetable pests in Benin-Farmers' preferences for eco-friendly nets as an alternative to pesticides. J. Environ. Manag. 2015, 147, 95-107.

55. Licciardi, S.; Assogba-Komlan, F.; Sidick, I.; Chandre, F.; Hougard, J.M.; Martin, T. A temporary tunnel screen as an eco-friendly method for small-scale growers to protect cabbage crop in Benin. Int. J. Trop. Insect Sci. 2008, 27, 152-158. 
56. Simon, S.; Assogba-Komlan, F.; Adjaïto, L.; Mensah, A.; Coffi, H.; Ngouajio, M.; Martin, T. Efficacy of insect nets for cabbage production and pest management depending on the net removal frequency and microclimate. Int. J. Pest Manag. 2014, 60, 208-216.

57. Sauphanor, B.; Severac, G.; Maugin, S.; Toubon, G.; Capowiez, Y. Exclusion netting may alter reproduction of the codling moth (Cydiapomonella) and prevent associated fruit damage to apple orchards. Entomol. Exp. Appl. 2012, 145, 134-142.

58. Gogo, E.O.; Saidi, M.; Itulya, F.M.; Martin T.; Ngouajio, M. Microclimate modification using eco-friendly nets for high quality tomato transplant production by small-scale farmers in East Africa. HortTechnology 2012, 22, 292-298.

59. Saidi, M.; Gogo, E.O.; Itulya, F.M.; Martin, T.; Ngouajio, M. Microclimate modification using eco-friendly nets and floating row covers improves tomato (Solanum lycopersicum) yield and quality for small holder farmers in East Africa. Agric. Sci. 2013, 4, 577-584.

60. Vidogbèna, F.; Adégbidi, A.; Assogba-Komlan, F.; Martin, T.; Ngouajio, M.; Simon, S.; Tossou, R.; Parrot, L. Cost-benefit analysis of insect nets use in cabbage in real farming conditions among smallholder farmers in Benin. Crop Prot. 2015, in press.

61. Carson, R.T.; Richard, T. Carson: Contingent Valuation: A Comprehensive Bibliography and History; Springer US: New York, NY, USA, 2002.

62. Carlson, R.T.; Louviere J.J. A common nomenclature for stated preference approaches. Environ. Resour. Econ. 2011, 49, 539-559.

63. République du Bénin. Institut National de la Statistique et de Analyse Économique du Bénin, 2013. Institut National de la Statistique et de l'Analyse Economique. Available online: http://www. insae-bj.org/ (accessed on 17 September 2015).

64. Aoudji, A.K.N.; Adégbidi, A.; Ganglo, J.C.; Agbo, A.; Yêvidé, A.S.I.; de Cannière, C.; Lebailly, P. Satisfaction across urban consumers of smallholder-produced teak (Tectona grandis L.f.) poles in South Benin. Forest Policy Econ. 2011, 13, 642-651.

65. Coulibaly, O.; Nouhoheflin, T.; Aitchedji, C.C.; Cherry, A.J.; Adegbola, P. Consumers' perceptions and willingness to pay for organically grown vegetables. Int. J. Veg. Sci. 2011, 17, 349-362.

66. Hai, N.M.; Moritaka, M.; Fukuda, S. Willingness to pay for organic vegetables in Vietnam: An empirical analysis in Hanoi capital. J. Fac. Agric. Kyushu Univ. 2013, 58, 449-458.

67. Hartter, J. Attitudes of rural communities towards wetlands and forest fragments around Kibale National Park, Uganda. Hum. Dimens. Wildl. 2009, 14, 433-447.

68. McFadden, D. Conditional logit analysis of qualitative choice behavior. In Frontiers in Econometrics; Zarembka, P., Ed.; Academic Press: New York, NY, USA, 1974; pp. 105-142.

69. Hanemann, W.M. Willingness to pay and willingness to accept: How much can they differ? Am. Econ. Rev. 1991, 81, 635-647.

70. Mitchell, R.C.; Carlson, R.T. Using Surveys to Value Public Goods: The Contingent Valuation method; Resources for the Future: Washington, DC, USA, 1989.

71. Alberini, A. Optimal designs for discrete choice contingent valuation surveys: Single-bound, double-bound, and bivariate models. J. Environ. Econ. Manag. 1995, 28, 287-306.

72. Peterson, M. Using PROC LOGISTIC to Estimate Willingness to Pay for Fresh Produce; California Polytechnic State University: San Luis Obispo, CA, USA, 2009. 
73. Murphy, J.J.; Allen, P.G.; Stevens, T.H.; Weatherhead, D. A meta-analysis of hypothetical bias in stated preference valuation. Environ. Resour. Econ. 2005, 30, 313-325.

74. List, J.A.; Gallet, C.A. What experimental protocol influence disparities between actual and hypothetical stated values? Environ. Resour. Econ. 2011, 20, 241-254.

75. Loomis, J.B. Strategies for overcoming hypothetical bias in stated preference surveys. J. Agric. Resour. Econ. 2014, 39, 34-46.

76. Loomis, J.; Pierce, C.; Manfredo, M. Using the demand for hunting licenses to evaluate contingent valuation of estimates of willingness to pay. Appl. Econ. Lett. 2000, 7, 435-438.

77. Carson, R.; Groves, T. Incentive and informational properties of preference questions. Environ. Resour. Econ. 2007, 37, 181-210.

78. Landry, C.E.; List, J.A. Using ex ante approaches to obtain credible signals for value in contingent markets: evidence from the field. Am. J. Agric. Econ. 2007, 89, 420-429.

79. Vossler, C.A.; Evans, M.F. Bridging the gap between the field and the lab: Environmental goods, policy maker input, and consequentiality. J. Environ. Econ. Manag. 2009, 58, 338-345.

80. Little, J.; Berrens, R. Explaining disparities between actual and hypothetical stated values: Further investigation using meta-analysis. Econ. Bull. 2004, 3, 1-13.

81. Ngigi, M.W.; Okello, J.J.; Lagarkvist, C.; Karanja, N.; Mburu, J. Assessment of developing-country urban consumers' willingness to pay for quality of leafy vegetables: The case of middle and high income consumers in Nairobi, Kenya. In Proceeding of the Joint 3rd African Association of Agricultural Economists (AAAE) and 48th Agricultural Economists Association of South Africa (AEASA) Conference, Cape Town, South Africa, 19-23 September 2010.

82. Xia, W.; Zeng, Y. Consumer's Willingness to Pay for Organic Food in the Perspective of Meta-Analysis, 2008. International Conference on Applied Economics. Available online: http://kastoria.teikoz.gr/icoae2/wordpress/wp-content/uploads/articles/2011/10/110-2008.pdf (accessed on 17 September 2015)

83. Lemay-Boucher, P.; Dagnelie, O. The divorced financial spheres of Beninese spouses. J. Int. Dev. 2012, 26, 46-58.

84. Smith, F.I.; Eyzaguirre, P. African leafy vegetables: Their role in the world health organization's global fruit and vegetables initiative. Afr. J. Food Agric. Nutr. Dev. 2007, 7, 1-17.

85. Food and Agriculture Organization. Fruit and vegetables for health. In Proceeding of Joint WHO/FAO Workshop, Kobe, Japan, 1-3 September, 2004.

86. Oboubie, E.; Keraita, B.; Danso, G.; Amoah, P.; Cofie, O.O.; Raschid-Sally, L.; Drechsel, P. Irrigated Urban Vegetable Production in Ghana: Characteristics, Benefits and Risks; IWMI: Accra, Ghana, 2006.

87. Penau, S.; Hoehn, E.; Roth, H.R.; Escher, F.; Nuessli, J. Importance and consumer perception of freshness of apples. Food Qual. Prefer. 2006, 17, 9-19.

88. Sakagami, M.; Sato, M.; Ueta, K. Measuring consumer preferences regarding organic labelling and the JAS label in particular. N. Z. J. Agric. Res. 2006, 49, 247-254.

89. Resano, H.; Sanjuan, A.I.; Albisu, L.M. Consumers' acceptability of cured ham in Spain and the influence of information. Food Qual. Prefer. 2007, 18, 1064-1076. 
90. Tregear, A.; Giraud, G. Geographical indications, consumers and citizens. In Labels of Origin for Food: Local Development, Global Recognition; Barham, E., Sylvander, B., Eds.; CABI: Oxfordshire, UK, 2011; pp. 63-74.

91. Skuras, D.; Vakrou, A. Consumers' willingness to pay for origin labelled wine. Br. Food J. 2002, 104, 898-912.

92. Stefani, G.; Romano, D.; Cavicchi, A. Consumer expectations, liking and willingness to pay for specialty foods: Do sensory characteristics tell the whole story? Food Qual. Prefer. 2006, 17, 53-62.

93. Ahouangninou, C.; Martin, T.; Edorh, P.; Siddick, S.; Bio-Bangana, S.; Dion, S.; Samuel, S.; St-Laurent, L.; Boko, M.; Simon, S.; et al. Characterization of health and environmental risks of pesticide use in market-gardening in the rural city of Tori-Bossito in Benin, West Africa. J. Environ. Prot. 2012, 3, 241-248.

94. Lusk, J.L.; Marette, S. Welfare effects of food labels and bans with alternative willingness to pay measures. Appl. Econ. Perspect. Policy 2010, 32, 319-337.

95. Secrétariat de la Convention de Rotterdam. Appui à la Mise en œuvre de la Convention de Rotterdam. Available online: http://www.pic.int/Portals/5/Proceedings/Report\%20country\%20 visits\%20Mayjune2010_final.pdf (accessed on 17 September 2015).

96. Brunet, N.; Guichard, L.; Omon, B.; Pingault, N.; Pleyber, E.; Seiler, A. L’indicateurde fréquence des traitements (IFT): Un indicateur pour une utilisation durable des pesticides. In A Propos de Réflexions sur Les Critères de Choix des Indicateurs de Pression Phytosanitaire; Guy, Y., Ed.; INRA: Paris, France, 2007; pp. 131-141.

(C) 2015 by the authors; licensee MDPI, Basel, Switzerland. This article is an open access article distributed under the terms and conditions of the Creative Commons Attribution license (http://creativecommons.org/licenses/by/4.0/). 